\title{
Free Fibular Osteoseptocutaneus Flap for Reconstruction Giantameloblastoma
}

\author{
Rachmat Wiardi ${ }^{1}$, Irra Rubianti $\mathrm{W}^{1}$
}

\begin{abstract}
Ameloblastoma is a tumor originating from odontogenic epithelial cells. The tumor is located in the gray zone between benign and malignant neoplasms. These tumors can occur at any age. Although traditionally divided as solid and cystic ameloblastoma, nearly all showed cystic changes. These tumors are invasive and have a very high recurrence rate. Ameloblastoma is an odontogenic tumor that is often found. These tumors are generally diagnosed in the fourth and fifth decade. Approximately $80 \%$ of these tumors occur in the jaw, with three-quarters are in the molar region and ramus. Approximately $20 \%$ of them occurred in the premolar and incisivum. Operative therapy was elected a radical resection of the affected parts of the jaw, followed by reconstruction. Bridging titanium plate can be used to replace part of lost bone and serves as a means of reconstruction. Various methods of reconstruction of the mandible can be done by using a bone graft from the calcaneus, fibula, ribs, scapula, iliac crest, or flap reconstruction. We report a case of male patients at entry RSHS Hospital May 11, 201018 years old with complaints arising the lump under the tongue \pm 8 years ago, accompanied by difficulty eating, difficulty speaking, and shortness of breath. Patients in the diagnosis of ameloblastoma of the mandible on the basis of anatomic pathology examination. It was decided to do the reconstruction of segmental mandibulectomy and free fibular osteoseptocutaneous free flap with multiple osteotomy. Patients go home in improvement condition.
\end{abstract}

Keywords: ameloblastoma, free fibular flap osteoseptocutaneus

Ameloblastoma merupakan suatu tumor epitelial odontogenik yang berasal dari jaringan pembentuk gigi, bersifat jinak, tumbuh lambat, penyebarannya lokal invasif dan destruktif serta mengadakan proliferasi kedalam stroma jaringan ikat. Tumor ini mempunyai kecenderungan untuk kambuh apabila tindakan operasi tidak memadai. Sifat yang mudah kambuh dan penyebarannya yang ekspansif dan infiltratif ini memberikan kesan ganas dan oleh karena sifat penyebarannya maupun kekambuhannya lokal maka tumor ini sering disebut sebagai locally malignancy. ${ }^{1}$

Etiologi ameloblastoma sampai saat ini belum diketahui dengan jelas, tetapi beberapa ahli mengatakan bahwa ameloblastoma dapat terjadi setelah pencabutan gigi, pengangkatan kista dan atau iritasi lokal dalam rongga mulut. ${ }^{2,3}$ Patogenesis dari tumor ini, melihat hubungan dengan jaringan

\footnotetext{
1. Bagian Bedah Plastik, Fakultas Kedokteran Universitas Padjadjaran Rumah Sakit Hasan Sadikin Bandung
}

pembentuk gigi atau sel-sel yang berkemampuan untuk membentuk gigi tetapi suatu rangsangan yang memulai terjadinya proliferasi sel-sel tumor atau pembentuk ameloblastoma belum diketahui. ${ }^{4,5}$ Shafer dkk. ${ }^{2}$ mengemukakan kemungkinan ameloblastoma berasal dari sumber-sumber sisa sel organ enamel (hertwig's sheat, epitel rest of mallassez), gangguan pertumbuhan organ enamel, epitel dinding kista odontogenik terutama kista dentigerous dan sel epitel basal permukaan rongga mulut ${ }^{2}$.

Ameloblastoma dapat terjadi pada segala usia, namun paling banyak dijumpai pada usia dekade 4 dan 5. Tidak ada perbedaan jenis kelamin, tetapi predileksi pada golongan penderita kulit berwarna. Ameloblastoma dapat mengenai mandibula maupun maksila, paling sering pada mandibula sekitar $81 \%$ - 98\%, predileksi di daerah mandibula $60 \%$ terjadi diregio molar dan ramus, $15 \%$ regio premolar, dan $10 \%$ regio simfisis ${ }^{2,3,5,7}$. 
Gambaran klinik dalam tahap awal jarang menunjukkan keluhan, oleh karena itu tumor ini jarang terdiagnosa secara dini, umumnya diketahui setelah 4 sampai dengan 6 tahun. ${ }^{3,7,8}$ Pembengkakan dengan berbagai ukuran yang bervariasi sehingga dapat menyebabkan deformitas wajah, warna sama dengan jaringan sekitarnya, konsistensi bervariasi ada yang keras dan kadang ada bagian yang lunak, berbatas tegas, terjadi ekspansi tulang ke arah bukal dan lingual, tumor ini meluas ke segala arah mendesak dan merusak tulang sekitarnya, terdapat tanda egg shell cracking atau pingpong ball phenomena bila massa tumor telahmendesak korteks tulang dan tulangnya menipis, tidak ada rasa nyeri dan tidak ditemukan parestesi, mukosa sekitas tumor tidak mengalami ulserasi. Hanya pada beberapa penderita benjolan disertai rasa nyeri, berkurangnya sensibilitas daerah distribusi n.mentalis dan kadangkadang terdapat ulserasi oleh karena penekanan gigi apabila tumor sudah mencapai ukuran besar. ${ }^{1,3}$ Dapat dilakukan fungsi aspirasi biasanya berisi cairan berwarna merah kecoklatan. Gigi geligi pada daerah tumor berubah letak dan goyang. Bila terjadi infeksi sekunder maka ulserasi, fistula bahkan jaringan granulasi pun dapat dijumpai, demikian juga rasa nyeri, parestesi,dan tanda-tanda inflamasi. ${ }^{1,3}$

Gambaran radiologis berupa lesi unilokuler atau multilokuler dengan gambaran seperti sarang tawon (honey comb appearance)pada lesi yang kecil dan gambaran busa sabun (soap bubble appearance) pada lesi yang besar. Hal ini merupakan proses osteolitik, karena ameloblastoma tumbuh secara lambat, secara radiologis tepinya berbatas jelas halus, corticated dan curved, terdapat resorpsi akar dan bergesernya gigi jauh dari tempat asal. ${ }^{10}$ Menurut gambaran radiologis ameloblastoma dibagi menjadi 3, yaitu konvensional solid/multikistik (86\%), unikistik (13\%) dan ekstra osseous (1\%) Computed tomografi (CT-scan) memberikan gambaran anatomi dari potongan jaringan secara 2 dimensi dan 3 dimensi dengan akurat. Keuntungan dari teknik ini yaitu tidak terjadi gambaran yang tumpang tindih dan memberikan gambaran jaringan secara detail dari perusahaan daerah yang terlibat. ${ }^{11}$

Shafer dkk. ${ }^{2}$ membedakan gambaran histopatologis dari ameloblastoma menjadi folikuler, pleksiform,acantomatous, granuler dan sel basal. Secara hisptopatologis, terdapat pulaupulauepitel atau lembaran yang bagian luar dilapisi sel-sel kolumnar, pada bagian tengah ditemukan sel stelat yang menyerupai stelat retikulum dari enamel organ dan stroma terdiri dari jaringan ikatfibrosa. Gambaran histopatologi pada ameloblastoma, dapat hanya satu jenis saja atau dapat terdiri dari berbagai jenis pola. Yang paling sering ditemukan adalah tipe folikuler dan pleksiform. ${ }^{1,2,3}$ Ameloblastoma mandibula dapat memperlihatkan gambaran klinis dan radiografis yang mirip dengan kelainan lain pada mandibula. Sebagai diagnosis banding adalah osteosarkoma, calcifying ephitelial odontogenik tumor, ossifying fibroma, dan kista dentigerus. ${ }^{12}$ Penatalaksanaan yang tepat masih diperdebatkan. Tingkat rekurensi berkisar antara 55-90\% setelah perawatan secara konservatif., ${ }^{1,3}$ Mengingat besarnya tingkat rekurensi tersebut, pendekatan secara radikal (reseksi) dapat dipertimbangkan sesuai indikasi, meskipun berakibat hilangnya sebagaian tulang rahang. Bridging plate titanium dapat digunakan untuk mengganti sebagian tulang yang hilang dan berfungsi sebagai alat rekonstruksi. Dapat juga rekonstruksi dengan menggunakan tulang kalkaneus, fibula, kosta, skapula maupun krista

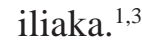

Indikasi operasi berdasarkan luas dan besarnya jaringan yang terlibat, struktur histologis dari tumor dan keuntungan yang didapat. ${ }^{7,13}$ Menurut Ohishi, indikasi perawatan konservatif adalah pada penderita usia muda dan ameloblastoma unikistik. Sedangkan indikasi perawatan radikal adalah ameloblastoma tipe solid dengan tepi yang tidak jelas, lesi dengan gambaran soap bubble, lesi yang tidak efektif dengan penatalaksanaan secara konservatif dan ameloblastoma ukuran besar. Penatalaksanaan secara radikal berupa reseksi segmental, hemimandibulektomi, dan reseksi marginal (reseksi enblok). ${ }^{14}$

Reseksi marginal (reseksi enblok) merupakan teknik untuk mengangkat jaringan tumor dengan mempertahankan kontinuitas korteks tulang mandibula bagian bawah yang masih intak. Reseksi enblok ini dilakukan secara garis lurus dengan bor dan atau pahat atau gergaji, 1-2 cm dari tepi batas tumor secara rontgenologis yang diperkirakan batas minimal reseksi. Tindakan dapat dilakukan secara intra maupun ekstra oral, hal ini tergantung pada seberapa besar untuk mendapat eksposure yang adekuat sampai ke ekstensi tumor. ${ }^{13,14}$ 
Rekontruksi mandibula ditinjau dari fungsi dan kosmetik, organ ini mempengaruhi bentuk wajah, fungsi bicara, mengunyah dan menelan. Beberapa cara dapat dipakai antara lain menggunakan bahan aloplastik, misalnya bridging plate titanium dan autogenous bone grafting misalnya tandur tulang iga, krista iliaka dan tibia serta dapat juga secara kombinasi aloplastik material dengan autogenous bone grafting. ${ }^{14}$

Flap merupakan suatu unit jaringan yang dipindahkan dari satu area (donor site) ke area yang lain (recipient site) dengan masih mempertahankan sistem aliran darahnya sendiri. ${ }^{20}$ Flap kulit dapat diambil dengan berbagai cara dan bentuk dalam rangka menutup defek jaringan yang ada pada daerah resipien. Flap kulit digunakan sebagai penutup luka saat kemampuan vaskuler dari dasar luka dianggap tidak mencukupi kebutuhan yang diperlukan pada skin graft. ${ }^{21}$

\section{Klasifikasi flap kulit ${ }^{20,21}$}

Skin flap dapat diklasifikasikan berdasarkan: Anatomi vaskularisasinya, metoda penggunaannya, komponen jaringannya.

1. Klasifikasi berdasarkan anatomi vaskularisasinya: Axial pattern flap, neurocutaneus flap, musculocutaneus flap.

2. Klasifikasi berdasarkan metode penggunaannya

Free flap: ukurannya bervariasi, termasuk di dalamnya kulit, otot, fascia dan tulang, benar-benar dilepaskan dari aliran darah asalnya, membutuhkan anastomose secara mikrosurgikal. Peninsular flap: Ditandai dengan adanya pedikel kutaneus bisa di proksimal maupun distal, digunakan sebagai rotasional flap, terbatas dalam kemampuannya menutup defek.Island flap: Ditandai dengan adanya vaskular pedikel, pedikel terdiri dari arteri, sebagian vena comitantes dikelilingi oleh jaringan seluler.

\section{Klasifikasi berdasarkan komponen jaringannya}

Fascial flap, termasuk didalamnya fascia dalam dan lapisan tipis subkutaneus sebagai pelindung jaringan suprafascial plexiform. Subcutaneus flap, dilakukan diseksi antara lapisan subdermal dan suprafascial. Merupakan vaskularisasi dengan pola axial.Cutaneus flap, lapisan diseksi di atas permukaan fascia superficial atau aponeurosis muscular (contoh groin flap atau scapular flap). Fasciocutaneus flap, di angkat secara en bloc termasuk di dalamnya kulit, jaringan subkutaneus dan fascia dalam. Diklasifikasikan menjadi tipe a-d.

\section{Klasifikasi fasciocutaneus flap}

Tipe A: Pembuluh darah multipel masuk ke dalam bagian dasar dari flap, Aksis panjang dari flap paralel dengan arah dari jaringan pembuluh darah, Flap dapat diangkat sebagai peninsular flap atau island flap.

Tipe B: Flap berdasarkan pada satu fasciocutaneus perforator, Flap dapat di angkat sebagai island flap atau peninsular flap.

Tipe C: Flap mendapat aliran darah dari multiple small perforator dari sepanjang pedikel kulit.

\section{ANATOMI ALIRAN DARAH FLAP}

Terdapat hubungan antara tipe dari vaskularisasi kulit dantipe dari aliran darah yang membedakan flap:

\section{Vaskularisasi langsung}

The long course arteries (contoh groin flap): Merupakan dasar dari flap dengan aksial vaskularisari, contoh groin flap.Arteri ini menembus fascia dalam secara obliq kemudian mengikuti jalannya di dalam jaringan subkutis bagian dalam.The neurocutaneus arteries (pada lower limb): Merupakan dasar dari flap neurocutaneus yang dapat di angkat tanpa khawatir terganggu fungsi sensasinya. Flap ini terbatas jumlahnya pada ekstremitas bawah. The interstitial arteries (contoh Chinese forearm flap): Terdiri dari jaringan ikat longgar yang menjadi dasar dari flap (disebut 'meso').

\section{Indirect vascularization}

Merupakan dasar dari flap muskulokutaneus. Aliran darah berasal dari arteri otot yang secara transversal menembus fascia dan didistribusikan ke kulit.

Terdapat beberapa indikasi untuk dilakukan free flap pada pembedahan rekonstruksi. Diantara adalah terdapatnya defek yang menyebabkan tulang, pembuluh darah, jaringan otak, persendian atau 
implant nonbiologi yang terpapar kepada dunia luar $^{15}$.

Perawatan pasca operasi reseksi enblok mandibular medikasi antibiotik dan analgetik, tidak perlu intermaksila fiksasi. Hindarkan trauma fisik pada muka atau rahang karena dapat menyebabkan fraktur mandibula.Jaga oral hygiene hingga luka operasi sembuh sempurna.Diet lunak dipertahankan 4-6 minggu.Jika diperlukan dapat dibuatkan prostesi gigi setelah dipertimbangkan bahwa telah terjadi internal bone remodeling tulang mandibula, lebih kurang 6 bulan pasca operasi ${ }^{16}$.

\section{LAPORAN KASUS}

Laporan kasus ini sudah mendapat ijin oleh penderita sendiri dan disetujui oleh komite medik RSHS.Seorang laki-laki 18 tahun di RSHS masuk Rumah Sakit tanggal 11 mei 2010 datang dengan keluhan timbul benjolan di bawah lidah sejak \pm 8 tahun yang lalu, mulanya sebesar kelereng, makin lama makin membesar hingga sebesar kepalan tangan orang dewasa. Benjolan \pm 6 bulan yang lalu pernah pecah dan sedikit mengecil namun membesar kembali hingga pasien mengeluh sulit makan, sulit bicara dan sesak nafas. Keluhan tidak disertai penurunan berat badan. Pasien seperti terlihat pada gambar 1.

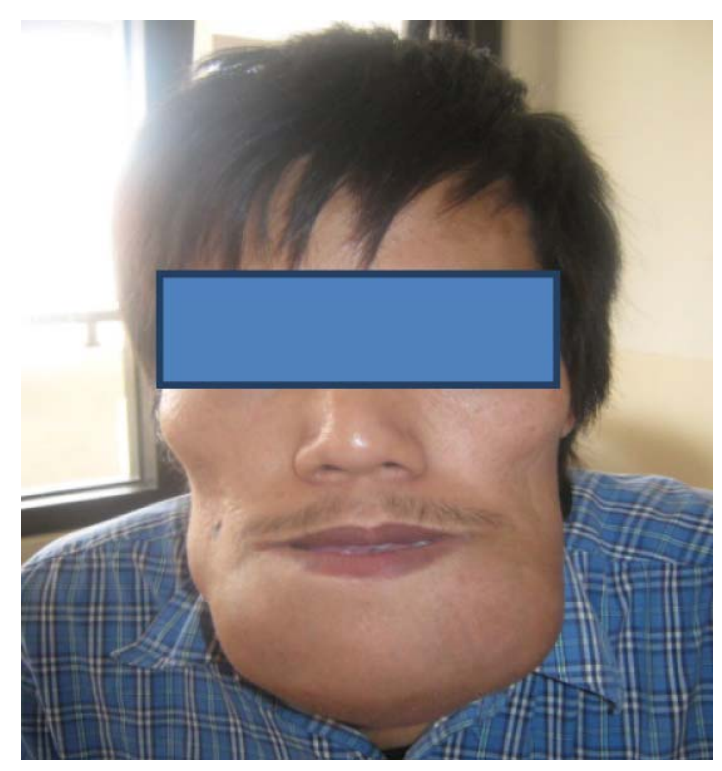

Gambar 1 Foto Klinis
Pemeriksaan fisik didapatkan keadaan umum pasien tanda vital dalam batas normal.Dari status generalis didapatkan konjungtiva tidak anemis. Pada pemeriksaan thoraks bentuk dan pergerakan dinding dada simetris, suara napas kiri sama dengan kanan dan tidak ditemukan ronkhi. Pada status lokalis didapatkan massa dengan konsistensi sebagian solid dan sebagian kistik dengan ukuran 15 x $10 \mathrm{~cm}$, terfiksir, tidak didapatkan nyeri tekan.

Pemeriksaan laboratorium didapatkan hasil sebagai berikut: Hb: 11,2, Leukosit: 9.800, trombosit: 163.000, hematokrit: 33, ureum: 31, kreatinin: 0,73, natrium: 134, kalium: 4,3.

Hasil rontgen panoramik memperlihatkan adanya gambaran multilokuler dari M2 kanan bawah sampai dengan M3 kanan bawah.

Pemeriksaan patologi anatomi didapatkan hasil sebagai berikut, sediaan dilapisi epitel gepeng berlapis yang akantosis. Inti sel dalam batas normal. Stroma tampak massa tumor yang terdiri dari sel bentuk bulat sampai spindle yang tumbuh hiperplastis membentuk pulau-pulau dengan bagian tengah yang hiperseluler dan ditemukan juga sel bentuk stellate. Inti sel dalam batas normal. Disekitarnya tampak sebukan massif sel radang limfosit, sel polimorfonuklear (PMN) dan perdarahan.Tidak tampak tanda ganas. Kesimpulan dari pemeriksaan tersebut adalah ameloblastoma dengan peradangan non spesifika/rmandibula.

Pasien didiagnosis kerja sebagai ameloblastoma/rmandibula kemudian diputuskan untuk dilakukan segmental madibulektomi + free fibular osteoseptocutaneous free flap dengan multiple osteotomi + Split Thicknes Skin Graft (STSG) pada daerah fibula.

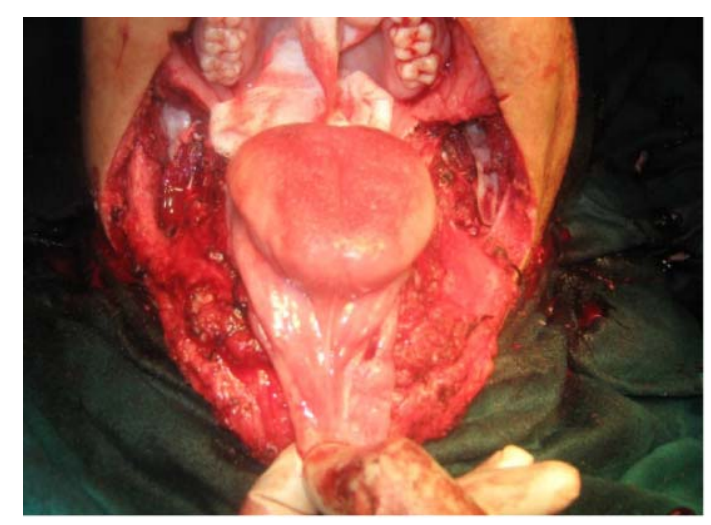

Gambar 2 Foto Intra Operatif 


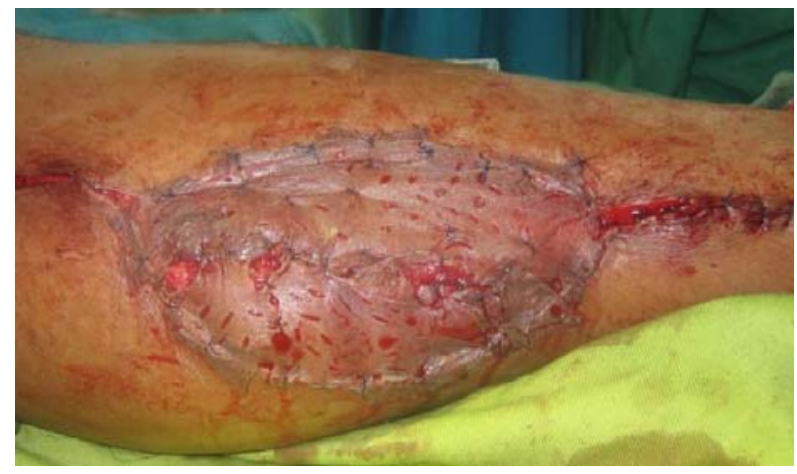

Gambar 3 Foto Intra Operatif

Dari durante operasi Bedah Onkologi ditemukan massa tumor mulai dari angulus mandibular kiri sampai angulus mandibular kanan, batas tegas, berisi cairan jernih bersepta-septa, dinding tipis dan rapuh, dilakukan segmental mandibulektomi.

Dari durante operasi Bedah Plastik ditemukan defek mandibular dengan ukuran $1 \mathrm{~cm}$ di atas angulus mandibula sinistra sampai dengan $1 \mathrm{~cm}$ di atas angulus mandibular dekstra. Angulus, korpus dan parasimfisis, simfisis kanan dan kiri dari mandibula dibuang. Gambar 2 merupakan gambar intra operasi. Diagnosis kerja post operasi adalah ameloblastomaa/r mandibula yang telah dilakukan segmental mandibulektomi + free fibular osteoseptocutaneous free flap dgn multiple osteotomi + Split Thicknes Skin Graft (STSG).

Pasien kemudian diperbolehkan pulang dengan keadaan perbaikan setelah dirawat selama 2 bulan dan disarankan kontrol teratur ke Bagian Bedah Plastik RSHS.

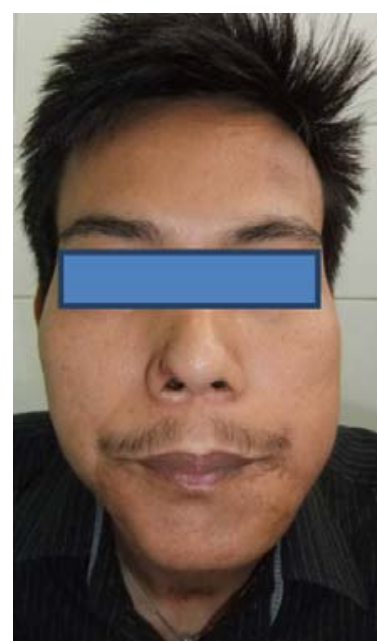

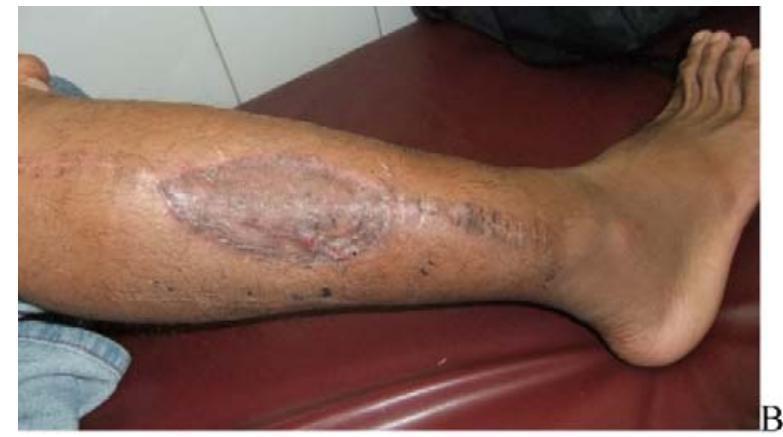

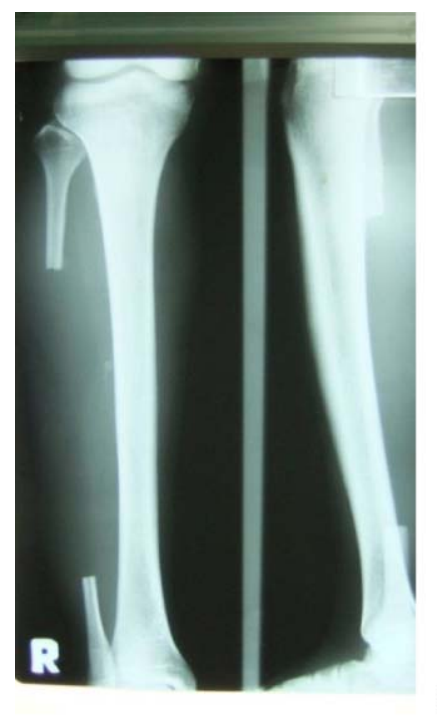

C

\section{PEMBAHASAN}

Telah di presentasikan kasus ameloblastoma pada mandibula yang telah dilakukan segmental mandibulektomi + free fibular osteoseptocutaneous free flap dgn multipel osteotomi + Split Thicknes Skin Graft (STSG) pada daerah fibula.

Indikasi operasi berdasarkan luas dan besarnya jaringan yang terlibat, struktur histologis dari tumor dan keuntungan yang didapat. Menurut Ohishi ${ }^{14}$, indikasi perawatan konservatif adalah pada penderita usia muda dan ameloblastoma unikistik. Sedangkan indikasi perawatan radikal adalah ameloblastoma tipe solid dengan tepi yang tidak jelas, lesi dengan gambaran soap bubble, lesi yang tidak efektif dengan penatalaksanaan secara konservatif dan ameloblastoma ukuran besar. Penatalaksanaan secara radikal berupa reseksi segmental, hemimandibulektomi dan reseksi marginal (reseksi enblok) yang melibatkan reseksi pada bagian rahang yang terkena tumor dan mengikutkan sekitar 1 sampai $2 \mathrm{~cm}$ dari tulang yang sehat. 
Indikasi di lakukannya free flap pada pasien ini adalah terdapatnya defek yang menyebabkan tulang, pembuluh darah, dan persendian yang terpapar kepada dunia luar.

Penatalaksanaan pada pasien ini diputuskan untuk di lakukan reseksi segmental berdasarkan indikasi ameloblastoma dengan jaringan yang terlibat luas dan ukuran yang besar, dari gambaran radiologis yang multilokuler.

Plat rekonstruksi mandibula memiliki keuntungan dari segi ${ }^{17}$ :

Tidak membutuhkan donor, kontur yang baik,kemampuan untuk membentuk kondilus, tidak membuat luka baru pada bagian tubuh lain.

Namun Plat rekonstruksi mandibula harus memerlukan biaya yang mahal

Komplikasi yang umum terjadi meliputi ${ }^{17}$ :

Ekstrusi/ekspose plat, kehilangan sekrup, fraktur plat, osteomyelitis.

Graft merupakan suatu bagian jaringan yang diambil dari satu tempat dan ditransplantasikan ke tempat lain, baik pada individu yang sama maupun yang berlainan. Tujuannya untuk memperbaiki cacat yang disebabkan oleh penyakit, kecelakaan, atau anomali pertumbuhan dan perkembangan. Bone graftmerupakan pilihan yang banyak digunakan untuk memperbaiki kerusakan tulang periodontal. Dengan graft tulang diharapkan ada perbaikan klinis pada tulang periodontal, hal ini lebih baik bila dibandingkan dengan cara bedah pembersihan biasa tanpa penambahan bahan graft ${ }^{18}$.

Terdapat dua fungsi utama graft terhadap tulang resipien yaitu mendorong terjadinya osteogenesis (pembentukan tulang) dan memberi dukungan mekanis pada kerangka resipien (mechanical support). Fungsi graft dan tulang untuk mendorong osteogenesis dapat melalui 3 cara, yaitu 19:

Membelah diri, yaitu sel dipermukaan graft dan tulang yang masih hidup pada saat dipindahkan, kemudian membelah diri dan membentuk tulang baru.Hal ini dapat terjadi pada cancelous autograft dan fresh cortical graft.Osteoinduksi, yaitu merupakan proses menarik sel pluripotensial dari resipien yang terdapat disekitar graft dan tulang. Hal ini terjadi karena graft dan tulang mengandung mediator osteoinduksi, seperti BMP (Bone Morphogenic Protein), merupakan matrik tulang sehingga aktifitasnya tidak dipengaruhi oleh ada tidaknya sel tulang yang hidup, tidak dirusak oleh freezing tetapi rusak oleh oktoklaf. BMP terdapat pada autograft, allograft, dan fresh bone, merupakan glikoprotein, dimana protein ini aktif pada demineralized bone matriks.Osteokonduksi, yaitu merupakan proses resorpsi graft, kemudian diganti oleh tulang baru dari respien secara bertahap. Konstribusi graft dimulai dengan proses osteokonduksi yaitu membuat kerangka sebagai matrik tulang di jaringan resipien. Kemudian dilanjutkan dengan stimulasi pembentukan tulang sebagai proses osteoinduksi

Keuntungan rekonstruksi dengan bone graft karena berasal dari jaringan tubuh sendiri, tetapi mempunyai beberapa kekurangan yaitu jumlahnya terbatas, sulit mengambil material graft, meningkatkan resiko infeksi, menambah waktu operasi meningkatkan resiko kehilangan darah dan menambah waktu anestesi, menyebabkan morbiditas serta kemungkinan resorbsi akar pada daerah donor $^{18}$.

Kasus dengan diagnosis kerja paskaoperasi ameloblastoma daerah mandibula yang telah dilakukan segmental mandibulektomi + free fibular osteoseptocutaneous free flap dgn multiple osteotomi + Split Thicknes Skin Graft (STSG). Setelah dilakukan perawatan selama 2 bulan dan mengalami perbaikan kemudian pasien diperbolehkan pulang. Disarankan kontrol teratur ke Bagian Bedah Plastik RSHS.Yang rencana selanjutnyaakan dilakukan protesa gigi atau implant gigi oleh Bagian Bedah Mulut.

\section{DAFTAR PUSTAKA}

1. Neville BW, Damn DD, Alen CM, Boiqout JE. Oral and maxillofacial pathology. Philadelphia: WB Sauders Co; 1995.p.512-8.

2. Shafer GS, Hine MR, Levy BM. A text book of oral pathology, 4thed. Philadelphia: WB Sauders Co; 1983.p.276-85.

3. Thoma KH. Oral Pathology 2nd ed, Vol 1. St.Louis: Mosby Co; 1970.p.481-9

4. Bhaskar SN. Synopsis of oral pathology 6th ed. London: Mosby Co: 1981.p.220-6,252-6, 
5. Regezi JA, Sciuba JJ. Oral Pathology clinical pathology correlation. Philadelphia: WB Sauders Co; 1989.p.337-9.

6. Small IA, Waldron CA. Ameloblastoma of the jaw. J Oral Surg Oral Med Oral Pathol 1995:8:281-91.

7. Laskin DW. Oral and maxillofacial Surgery, Vol II. St.Louis: CV Mosby; 1974.p.568-70

8. Archer WH. Oral and maxillofacial surgery, 5th ed, Vol.1. Philadelphia: WB Sauders Co; 1975.p.735-59

9. Pedlar D, Frame JW. Oral and maxillofacial surgery. Philadelphia: WB Sauders Co; 2001.p.109.

10. Farman AG, Nortje CJ, Wood RE. Oral and maxillofacial diagnostic imaging. St Louis: CV Mosby Co; 1993.p.239-43

11. Rothman SLG. Dental application of computed tomography. Quintessence Publishing Inc; 1998.p.156-7

12. Killey SK. An outline of oral surgery, part II. bristol: John Wright \& Sons Ltd; 1975.p.99-114.

13. Kruger GO. Text Book of oral Surgery, 4th ed. St. Louis:The Mosby co; 1974.p.568-70.
14. Ohishi M. Management of mandibula ameloblastoma the clinical basis for tratment alogaritm. J Oral Maxillofacial Surgery 1999:37.

15. Huang D, Wang Hai-wen; Reconstruction of soft tissue defect of the extremity with the perforator flap from inguinal region. Chinese medical journal; 2009;122 (23); 2861-64.

16. Keith DA. Atlas of oral and maxillofacial surgery. WB Sauders and co; 1992.p.99-101.

17. Dietrich T, Dibart S. Practical Periodontal Diagnosis and Treatment Planning. Wiley Blackwell: 100.

18. Kamran H. Dental Implants. Dalam: Perry DA, Beemsterboer PL, penyunting. Periodontology for the Dental Hygienist. 3rd ed. St Louis: Missouri, 2007:320-49.

19. Sheri GS. Implant Maintenance and the Dental Hygienist <http://www.adha.org/downloads/ sup_implant.pdf $>$

20. Charles H, Robert W. Beasley, Sherrell J. Aston, GRABB AND SMITH'S PLASTIC SURGERY, sixt edition, Lippincott Williams \& Wilkins, 2007.

21. Townsend, Courtney M., Sabiston Textbook of Surgery: 16th edition, Saunders, 2001. 